\title{
Preparation and Processing of Ancient Millets for the Production of Nutritious Malt Powder with Natural Fruit Flavours
}

\author{
Himabindu $\mathbf{P}^{1 *}$ and Devanna $\mathbf{N}^{2}$ \\ ${ }^{1}$ Department of Food Technology, Jawaharlal Nehru Technological University, Andhra Pradesh, India \\ ${ }^{2}$ Department of Chemistry, Jawaharlal Nehru Technological University, Andhra Pradesh, India
}

*Corresponding author: Himabindu P, Department of Food Technology, Jawaharlal Nehru Technological University, Anantapur, Andhra Pradesh, India, Tel: 085542 72438; E-mail: bindu_ft2000@yahoo.co.in

Received date: April 13, 2017, Accepted date: April 19, 2017, Published date: April 26, 2017

Copyright: @ 2017 Himabindu P, et al. This is an open-access article distributed under the terms of the Creative Commons Attribution License, which permits unrestricted use, distribution, and reproduction in any medium, provided the original author and source are credited.

\begin{abstract}
An experiment was undertaken with an attempt to exploit the commercial use of Kodo and little millet, and to improve the nutritive value of the products developed from the grains by incorporating fruits such as mango \& sapota. Kudos millet and little millet grains were malted by soaking in potable water for 18 hours, germination for 30 hours followed by drying at $50^{\circ} \mathrm{C}$ till moisture was reduced to $5 \%$ and then milled in two different ways, First sample was prepared by using combination of 50:50 Kodo and Little millet flour and other ingredients such as 100 grams of milk powder, dried sapota powder $(50 \mathrm{~g})$, joggery $(50 \mathrm{~g})$. And for sample-2 Kodo millet and little millet flour (50:50) and other ingredients such as milk powder $(100 \mathrm{~g})$, dried sapota powder $(50 \mathrm{~g})$ and sugar $(50 \mathrm{~g})$ are added. In the same way another two samples are prepared by using dried mango powder. All prepared samples are evaluated by sensory panel. Results revealed that among all the formulations tried, the sapota fruit flavoured malt with joggery got higher sensory scores. The physico-chemical characteristics of the most acceptable malt powder were analyzed. When compared with normal ragi malt powder the sample contains significantly higher amounts of protein, fiber and minerals and vitamins (i.e., Calcium, Iron and Phosphorous) the most acceptable malt powder is then packed in HDPE and subjected for storage study for a period of 3 months at cool and dry place. Sensory scores show decreasing trend in overall acceptability of the products with increase in storage.
\end{abstract}

Keywords Kodo millet; Little millet; Malted; Fruits; Mango; Sapota; Storage study

\section{Introduction}

In recent years, millets are recognized as important substitutes for major cereal crops to cope up with world food shortage and to meet the demands of increasing population of both developed and developing countries [1-3]. Millets are the group of highly variable small seeded grasses widely grown around the world as cereal crops or grains for fodder and human food. Millets are important crops in semiarid tropics of Asia and Africa (especially in India, Mali, Nigeria and Niger) with $97 \%$ of millet production in developing countries, the crop favored due to its productivity and short growing season under dry, high-temperature condition [4,5]. The kodo millet contains high amounts of polyphenols an antioxidant compound, they also have high on fibre and low on fat. Kudos millet inhibited glycation and cross linking of collagen, Kudo millets are good for diabetics. Little millet seeds are smaller than other millets like Foxtail millet. Little millet is high in iron content, high in fibre like kodo millet and has high antioxidant activity. It helps diabetics and problems related to stomach. Malting of grains causes a significant reduction in the anti-nutritional components thus improving the availability of nutrients of malt. Malting has also been reported to help increase the in vitro digestibility, improves the sensory quality and extends the shelf life of the product [6-10].

Fruits also play a significant role in human nutrition. Daily consumption of fruit is recommended for significantly reducing the risk of chronic diseases and to meet the micronutrient requirement to fulfill the nutrient demand of the body for optimum health, fruits can be supplemented in various food products which can increase the palatability and nutritive contents of foods.

The consumers demand foods that are not only nutritious but also catering to their taste. Therefore there are high potentials for development of various value added food products having specific health and disease preventive properties. Attempts should be made for development of value added products with a combination of foods by which several nutrients could be supplied to the body through a single food item [11]. Hence the present study was conducted to develop fruit incorporated malt mix powder by standardizing and optimizing the fruit sapota and mango to be separately incorporated in to the malt mix. The most acceptable combination was subjected to storage studies and physico-chemical analysis.

\section{Materials and Methods}

Kodo millet and little millet are procured from TIMBUCTU organization (Penukonda, Anantapur district) mango, sapota and other ingredients required for the development of malt powder were procured from local market. The kodo millet is stored at room temperature.

Mango and sapota were taken separately and whole pulp was extracted from the fruit and the pulp is kept in cabinet dryer at $600^{\circ} \mathrm{C}$ till completely dry. The dried fruit material was ground into powder by using grinder [12]

The malt powder was prepared in two ways: First sample was prepared by using combination of 50:50 Kodo and Little millet flour 
Page 2 of 3

and other ingredients such as 100 grams of milk powder, dried sapota powder $(50 \mathrm{~g})$, joggery $(50 \mathrm{~g})$. And for sample-2 kudos millet and little millet flour (50:50) and other ingredients, milk powder $(100 \mathrm{~g})$, dried sapota powder $(50 \mathrm{~g})$ and sugar $(50 \mathrm{~g})$ are added. In the same way another two samples were prepared by using dried mango powder [13].

\section{Testing acceptability of the product}

Malted finger millet powder is taken as control. The experimental products along with control were evaluated, by a selected panel of 8 judges, for their sensory characteristics by using composite scoring method [14-16]. A score card was prepared separately for each type of malt mix and numerical scores were assigned for each attribute. The attributes considered during the study were flavour, taste, mouth feel, colour, appearance and overall acceptability. Judges were to evaluate based on scores assigned. The best combination (malt with sapota and joggery) was identified. This sample was taken for further nutritional analysis and storage study.

\section{Nutrient and physico-chemical analysis}

The control (FMMF) and the most acceptable (SIMMF) samples were analyzed for moisture, crude fibre and fat by using the method of AOAC, 1990. The protein content was estimated using Lowry's colorimetric method and calculated as $\mathrm{g} \%$ of protein (Lowry, et al., 1951). Carbohydrates are also determined by using the method of DGHS manual [17].

\section{Storage studies}

Packaging of the best combination of powder was done in HDPE and laminated pouches and the samples were stored at ambient temperatures. The acceptability of the stored sample was evaluated by the same panel of judges selected earlier [18]. A five point hedonic scale was used to rank each of the attribute of the products. Sensory evaluation was carried out periodically after 15, 30, 45 and 60 days during the 2 months storage period, by the same panel of judges.

\section{Results and Discussion}

\section{Acceptability of the product}

The sensory evaluation of the newly developed products revealed that the combination of $50 \%$ sapota powder and incorporated malt powder obtained least standard deviation (SD) among the mango incorporated mixes. This powder was selected for quality evaluation and storage studies.

\section{Nutrient and physico-chemical analysis}

The result for the nutrient and physico-chemical analysis of malted finger millet flour (control). Most acceptable sapota incorporated kodo and little millet flour (SIMMF), is presented in Table 1 and Figure 1.

\begin{tabular}{|l|l|l|}
\hline Parameters & FMMF & SIMMF \\
\hline CHO & 73.2 & 65.6 \\
\hline Moisture & 11.35 & 10.2 \\
\hline Protein & 7.83 & 8.21 \\
\hline
\end{tabular}

\begin{tabular}{|l|l|l|}
\hline Fat & 1.15 & 2.7 \\
\hline Crude fibre & 3.91 & 8.6 \\
\hline Ash & 1.88 & 3.8 \\
\hline
\end{tabular}

Table 1: Nutrient and physicochemical composition of malt mixes.



Figure 1: Nutrient and physicochemical composition of malt mixes.

Values are means of two observations; MFMF malted finger millet flour, SIMMF most acceptable sapota incorporated malted millet flour.

The carbohydrate content is low in sapota incorporated malt when compared to control. This may be attribute to the higher protein content in the most acceptable sample than that of control $[19,20]$.

Moisture content was decreased in the sample than that of control due to decrease of fruit moisture up to 5\%. A significant increase in the protein content was observed on malting of kodo and little millet and decrease in carbohydrates trough oxidation during germination and loss of low molecular weight nitrogen and rising of grains.

The fat content was increased in sample due to incorporation of sapota. The higher content of fat in sapota could have resulted in higher value of fat obtained in the sapota incorporated sample [21-23].

There was a significant increase in crude fibre in sample than that of control, it may be due to the kodo millet is an excellent source of fibre. The ash content of the sample was increased compared to the control due to the addition of more ingredients like fruit powder, milk powder, and joggery etc.

\section{Storage studies}

Table 2 indicates the results for mean scores for different attributes on sensor test and Figure 2 shows the analysis of variance for overall acceptability of the stored products. The results for storage studies revealed that both the control and sample were acceptable upto 30 days. Both the samples were acceptable upto 60 days with mild changes [24-27].

Storage studies also revealed that both the control and sample packed in HDPE are more acceptable than that of packed in laminated pouches. 


\begin{tabular}{|l|l|l|l|l|l|l|}
\hline Days & Flavour & Taste & Mouth feel & $\begin{array}{l}\text { Colou } \\
\mathbf{r}\end{array}$ & $\begin{array}{l}\text { Appearanc } \\
\mathbf{e}\end{array}$ & $\begin{array}{l}\text { Overall } \\
\text { acceptabilit } \\
\mathbf{y}\end{array}$ \\
\hline
\end{tabular}

Sample in HDPE pouch

\begin{tabular}{|l|l|l|l|l|l|l}
\hline 15 & 4.4 & 4.6 & 4.8 & 4.8 & 4.6 & 4.64 \\
\hline 30 & 4.2 & 4.6 & 4.6 & 4.4 & 4.0 & 4.36 \\
\hline 45 & 3.8 & 4.0 & 4.2 & 4.0 & 4.0 & 4.0 \\
\hline 60 & 3.4 & 3.8 & 4.0 & 4.0 & 3.8 & 3.8 \\
\hline
\end{tabular}

Sample in laminated pouch

\begin{tabular}{|l|l|l|l|l|l|l|}
\hline 15 & 4.4 & 4.4 & 4.8 & 4.8 & 4.6 & 4.60 \\
\hline 30 & 4.0 & 4.4 & 4.4 & 4.0 & 4.0 & 4.16 \\
\hline 45 & 3.8 & 4.0 & 4.2 & 4.0 & 3.8 & 3.96 \\
\hline 60 & 3.2 & 3.4 & 3.8 & 3.8 & 3.2 & 3.48 \\
\hline
\end{tabular}

HDPE: High Density PolyEthylene

Table 2: Sensory scores malt mixes on storage.

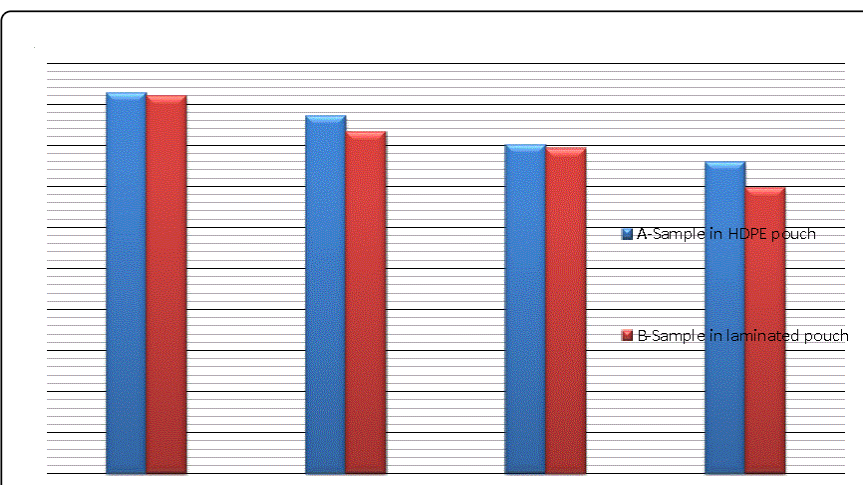

Figure 2: Shelf life studies of Sample A and B.

\section{Conclusion}

The present study concludes that fruit incorporated millet (kodo \& little) malt mix prepared with incorporation of $50 \%$ sapota powder was found to be best combination with respect to sensory evaluation. With increasing health consciousness among people and increasing demand of foods which reduce the risk of diseases, there is tremendous scope and market opportunity for development of such value added products which could find commercial value. The malt mix can be recommended as health foods for all age groups because consumption of nutrient dense foods such as those developed will not only help the nutritional status but also provide further health benefits.

\section{References}

1. Acs E, Kovacs Z, Matuz J (1996) Bread from corn starch for dietetic purposes. I. Structure formation. Cereal Res Comm 24: 441-449.

2. Acs, E, Kovacs Z, Matuz J (1996b) Bread from corn starch for dietetic. II. Formation of the visual and technological properties. Cereal Res Comm 24: 451-459.
3. Agu RC, Palmer GH (1998) A reassessment of sorghum for lager-beer brewing. Biores Tech 66: 253-261.

4. Akingbala JO, Rooney LW, Palacios LG, Sweat VE (1982) Thermal properties of sorghum starches.

5. Awika JM, Rooney LW (2004) Sorghum phytochemicals and potential impact on human health. Phytochemistry 65: 1199-1221.

6. Awika JM, McDonough CM, Rooney LW (2005) Decorticating sorghum to concentrate healthy phytochemicals. J Agri Food Chem 53: 6230-6234.

7. Badi SM, Hoseney RC (1976) Use of sorghum and pearl millet flours in cookies. Cereal Chem 53: 733-738.

8. Barredo-Moguel LH, Rojas de Gante C, Serna Saldivar SO (2001a) Comparisons between a commercial wort and a waxy sorghum wort fermented into lager beer, with emphasis on yeast growth and ethanol production. J Am Soc Brew Chem 59: 24-27.

9. Barredo-Moguel LH, Rojas de Gante C, Serna Saldivar SO (2001b) Alpha-amino nitrogen and fusel oils of sorghum worts fermented to lager beer. J Inst Brew 107: 367-372.

10. Belton PS, Delgadillo I, Halford NG, Shewry PR (2006) Kafirin structure and functionality. J Cereal Sci 44: 272-286.

11. Berti C, Riso P, Monti LD, Porrini M (2004) In vitro starch digestibility and in vivo glucose response of gluten-free foods and their gluten counterparts. Euro J Nutr 43: 198-204.

12. Beta T, Corke H (2001) Genetic and environmental variation in sorghum starch properties. J Cereal Sci 34: 261-268.

13. Beta T, Rooney LW, Waniska RD (1995) Malting characteristics of sorghum cultivars. Cereal Chem 72: 533-538.

14. Beta T, Corke H, Taylor JRN (2000) Starch properties of Barnard Red, a South African red sorghum of significance in traditional African Brewing. Starch/Staerke 52: 467-470.

15. Beta T, Corke H, Rooney LW, Taylor JRN (2000) Starch properties as affected by sorghum grain chemistry. J Sci Food Agri 81: 245-251.

16. Beta T, Rooney LW, Marovatsanga LT, Taylor JRN (2000) Effect of chemical treatments on polyphenols and malt quality in sorghum. J Cereal Sci 31: 295-302.

17. Brannan GL, Setser CS, Kemp KE, Seib PA, Roozeboom K (2001) Sensory characteristics of grain sorghum hybrids with potential for use in human food. Cereal Chem 78: 693-700.

18. Buffo RA, Weller CL, Gennadios A (1997) Films from laboratoryextracted sorghum kafirin. Cereal Chem 74: 473-475.

19. Buffo RA, Weller CL, Parkhurst AM (1997) Opimization of sulphur dioxide and lactic acid steeping concentrations for wet-milling grain sorghum. Transac Am Soc Agri Eng 40: 1643-1648.

20. Buffo RA, Weller CL, Parkhurst AM (1998) Wet-milling factors of sorghum and relationship to grain quality. J Cereal Sci 27: 327-334.

21. Byaruhanga YB, Erasmus C, Taylor JRN (2005) Effect of microwave heating on the functional properties of kafirin films. Cereal Chem 82: 565-573.

22. Carr TP, Weller CL, Schlegel VL, Cuppett SL, Guderian Jr DM, et al. (2005) Grain sorghum lipid extract reduces cholesterol absorption and plasma non-HDL cholesterol concentration in hamsters. J Nutr 135: 2236-2240.

23. Casier JPJ, de Paepe G, Willems H, Goffings G, Noppen H (1977) Bread from starchy tropical crops. II. Bread production from pure millet and sorghum flours, using cereal endosperm-cell wall-pentosan as a universal baking factor.

24. Cauvain SP (1998) Other cereals in breadmaking.

25. Choto CE, Morad MM, Rooney LW (1985) The quality of tortillas containing whole sorghum and pearled sorghum alone and blended with yellow maize. Cereal Chem 62: 51-55.

26. Chung OK, Ohm JB (2000) Cereal lipids.

27. Corredor DY, Bean SR, Schober T, Wang D (2006) Effect of decorticating sorghum on ethanol production and composition of DDGS. Cereal Chem 83: $17-21$. 